Article

\title{
Copper Isotope Compositions of Superoxide Dismutase and Metallothionein from Post-Mortem Human Frontal Cortex
}

\author{
Fiona Larner ${ }^{1,2, *}$, Catriona A. McLean ${ }^{3}$, Alex N. Halliday ${ }^{2,4}$ and Blaine R. Roberts ${ }^{5,6, *(D)}$ \\ 1 Department of Genetics, Melbourne Brain Centre, The University of Melbourne, Kenneth Myer Building, \\ 30 Royal Parade, Parkville 3010, Australia \\ 2 Department of Earth Sciences, University of Oxford, South Parks Road, Oxford OX1 3AN, UK \\ 3 Department of Anatomical Pathology, Alfred Hospital, Prahran 3004, Australia \\ 4 The Earth Institute, Columbia University, 104 Hogan Hall, 2910 Broadway, New York, NY 10025, USA \\ 5 The Florey Institute, University of Melbourne, Parkville 3010, Australia \\ 6 Cooperative Research Centre for Mental Health, Parkville 3010, Australia \\ * Correspondence: fiona.larner@stcatz.ox.ac.uk (F.L.); blaine.roberts@florey.edu.au (B.R.R.)
}

Received: 4 May 2019; Accepted: 3 July 2019; Published: 7 July 2019

\begin{abstract}
The natural copper isotopic compositions of superoxide dismutase and metallothionein from six post-mortem human frontal cortices were determined using a combination of size exclusion protein liquid chromatography, followed by anion exchange chromatography and multiple collector inductively-coupled plasma mass spectrometry. Superoxide dismutase was enriched in the heavier ${ }^{65} \mathrm{Cu}$ relative to the metallothionein fraction in all specimen pairs. The isotopic compositions were independent of copper content. This finding provides evidence that nitrogen ligands in protein copper binding sites will be enriched in heavy metal isotopes, and sulphur ligands will preferentially incorporate lighter isotopes in vivo. This in turn has implications for understanding isotopic distributions within different components in the body and the dominant ligands in different tissues. Differences in $\mathrm{Cu}$ isotope distributions between the two proteins were seen between Alzheimer's disease and healthy control samples, when normalised for sex.
\end{abstract}

Keywords: MCICPMS; Alzheimer's disease; isotope fractionation; copper; superoxide dismutase; metallothionein

\section{Introduction}

Trace metals are important for many biological functions and have a significant role in health and disease [1]. Loss of function in critical metalloenzymes results in an array of genetic diseases for example, Wilson's disease (mutation of ATP7B), Menkes (mutation of ATP7A) and aceruloplasminemia (mutation of ceruloplasmin). There is an increasing need for techniques to probe the role of trace elements in biology and provide further insight into metal-protein interactions in healthy and diseased states. Isotope compositions (e.g., the ratio of the amounts of ${ }^{63} \mathrm{Cu}$ to ${ }^{65} \mathrm{Cu}$ ) are a relatively new tool to probe the pathway of trace metals in biological systems. In contrast, there have been numerous applications in the geosciences and the environment (e.g., [2-4]). Natural stable isotope fractionation is caused by mass-dependent differences in energy requirements and the fact that some chemical processes preferentially incorporate lower free energy states in different isotopologues, as occurs during a change in phase, ligand coordination, or oxidation state [2-5]. Differences in the isotopic fractionation of copper, zinc and iron have been found in an array of diseases relative to healthy controls [6-11], as well as in the ranges of "healthy" values in relation to age, sex and dietary intake [12-15]. These differences have been found in diverse tissue types including serum, urine 
and breast tissue and are used to facilitate improved understanding of the mechanisms from the cellular level to the whole body. The interpretations of these results from humans are based on geochemical observations, computational simulations of metal-ligand interactions and a limited number of laboratory studies [4,12,16-21]. The isotopic compositions of trace metals in specific protein-metal complexes in the human body have not been studied, despite the fact that this is fundamental to the correct interpretation of such signatures (e.g., [22]). The objective of this study is to address this gap in knowledge, through a unique combination of metallo-biochemical techniques and high precision isotope ratio mass spectrometry.

The isotopic compositions of two copper binding metalloproteins, metallothionein (MT) and superoxide dismutase (SOD), enriched from seven specimens of human brain tissue from both healthy controls and those with Alzheimer's disease are presented. Metallothioneins and SODs are critical proteins for the mediation of oxidative stress [23,24]. Metallothioneins are important proteins with regards to the regulation of metal toxicity and transport, and various isoforms are found in many mammalian tissues including the liver and brain. The multiple cysteine residues bind metals with sulphur ligands, and a single molecule can contain up to seven bivalent metal ions and 20 monovalent ions [23]. Transition metals are key to SOD activity; two of the three human SOD isoforms contain copper and zinc. Of these isoforms, SOD1 is found in the cytosol of almost all human cells, and SOD3 is found extracellularly [24]. Unlike MT, the SOD copper-binding site is a nitrogen-rich histidine [25].

These two proteins have different, but critical roles in metal homeostasis, are spread widely throughout the body, and utilise different binding environments to interact with metals. Loss of MT function has been implicated in a range of diseases, including cancer [23], Parkinson's disease [26] and Alzheimer's disease [27]. Mutation of $\mathrm{Cu}-$ and $\mathrm{Zn}-\mathrm{SOD}$ results in familial amyotrophic lateral sclerosis, and although the link with the metal cofactors is still being elucidated, there are promising therapeutic developments that implicate a causal role for $\mathrm{Cu}$ in the disease [28,29].

The aim of this study is to demonstrate a novel combination of HPLC and high precision isotopic analysis for the isolation and subsequent determination of copper isotope compositions in cortex samples, as a new tool to investigate copper metabolic changes in neurodegenerative diseases.

\section{Results and Discussion}

The copper isotope composition of SOD relative to metallothionein was found to be significantly heavier in all specimens analysed as part of this study regardless of disease state and gender, with the exception of the female Alzheimer's disease specimen (AD3, Table 1) for which no significant difference in isotope composition was found between the two complexes.

Table 1. The copper isotopic composition of metallothionein and superoxide dismutase isolated from brain homogenates of diseased and non-diseased states and similar values for the same bonding environments from other studies.

\begin{tabular}{|c|c|c|c|c|c|c|c|}
\hline Sample & Sex & $\begin{array}{c}\text { Total } \mathrm{Cu}_{\text {SOD }} \\
(\mathrm{ng})\end{array}$ & $\begin{array}{c}\delta^{65} \mathrm{Cu}_{N} \\
(\% o)^{4}\end{array}$ & $\begin{array}{c}\text { Total } \\
\text { CuMT (ng) }\end{array}$ & $\begin{array}{c}\delta^{65} \mathrm{Cu}_{\mathrm{S}} \\
(\% \text { o })^{4}\end{array}$ & $\begin{array}{c}\Delta^{65} \mathrm{Cu}_{\mathrm{N}-\mathrm{S}} \\
(\% \text { oo })^{4}\end{array}$ & Source \\
\hline AD1 1,2 & Male & 180 & 0.34 & 43 & -0.25 & 0.59 & $\begin{array}{l}\text { this } \\
\text { study } 5\end{array}$ \\
\hline $\mathrm{AD} 2^{1}$ & Male & 86 & 0.36 & 30 & -0.08 & 0.44 & 5 \\
\hline $\mathrm{AD}^{1}$ & Female & 40 & -0.33 & 27 & -0.39 & 0.06 & 5 \\
\hline CON1 & Male & 83 & 0.37 & 26 & -0.42 & 0.79 & 5 \\
\hline $\mathrm{CON} 2^{3}$ & Female & 48 & 0.31 & 47 & 0.14 & 0.17 & 5 \\
\hline Yeast $_{S O D-M T}$ & & & & & & 0.53 & [4] \\
\hline RBCs-serum & Female & & 0.46 & & -0.24 & 0.60 & [12] \\
\hline RBCs-serum & Male & & 0.67 & & -0.28 & 0.95 & [12] \\
\hline
\end{tabular}

${ }_{1}^{1}$ National Institute of Aging (NIA) Reagan criteria; ${ }^{2}$ mean values obtained from brain analysed in replicate analysis;

${ }^{3}$ mean values of two female samples combined prior to isotopic analysis; ${ }^{4}$ isotopic composition given in reference to the binding ligand. ${ }^{5}$ this study. CON $=$ non-diseased states. For this study and [4], $\mathrm{N}=$ superoxide dismutase (SOD), $\mathrm{S}=$ metallothionein (MT); for [12], $\mathrm{N}=$ erythrocytes (RBCs), $\mathrm{S}=$ serum. 
A few other observations can be made from this dataset, which indicate that further study into this phenomenon is warranted. Despite the small sample set, the male specimens analysed appeared to have larger differences in copper isotope composition between the two metallo-protein complexes ( $\triangle^{65} \mathrm{Cu}_{\mathrm{SOD}-\mathrm{MT}}$ ) compared to the same values obtained from female specimens. All healthy control specimens had a larger $\Delta^{65} \mathrm{Cu}_{\mathrm{SOD}-\mathrm{MT}}$ compared to the sex-matched Alzheimer's disease isotope composition.

The direction of isotopic offset between these two proteins is consistent with previous in vitro and computational studies. Ab initio modelling and laboratory-based investigations [12,16-18,21] of protein-metal interactions have indicated that, because of the stronger bonds formed, heavier isotopes will preferentially bond to amino acids with harder ligands, such as nitrogen and oxygen, whereas softer ligands such as sulphur, will show a preference for lighter isotopes. In addition, when applicable, the oxidation state of the metal in question is also important. For example, $\mathrm{Cu}^{+}$will preferentially bind to soft ligands, whereas $\mathrm{Cu}^{2+}$ will be found in harder bonding environments [12]. Metallothionein binds metals through cysteine-based sulphur ligands [30], whereas SOD binds $\mathrm{Cu}$ through nitrogen ligands of histidine residues [31]. In general, the "rules" for isotopic fractionation due to bonding environment appear to translate well to the isotopic fractionation we observed for MT and SOD. The relative $\mathrm{Cu}$ isotopic fractionation between the two bonding environments found here $\left(\triangle^{65} \mathrm{Cu}_{\mathrm{SOD}-\mathrm{MT}}\right)$, however, was less than that calculated ab initio for cysteine-Cu and histidine-Cu bonds $\left(\Delta^{65} \mathrm{Cu}_{\text {his-cys }}=1 \%\right.$ o $)[10,17]$. The calculated isotopic fractionation was for a simpler system, which may account for the differences. For example, it does not take into account sequential isotopic fractionation that occurs due to the amino acid residues that compose the active sites of the $\mathrm{Cu}$-import/-transport proteins that move $\mathrm{Cu}$ from the gut throughout the body. In addition, due to the limited metal-protein exchange reactions and tight binding of metals to protein ligands, thermodynamic equilibrium may not have been reached in the biological system, and therefore, the calculated isotopic fractionation is in a different state to that measured. This highlights the importance of measuring isotopic compositions of the system of interest directly. Metallothionein and superoxide dismutase extracted from yeast cells cultured in a copper solution of known isotopic composition had a relative isotopic difference of $0.53 \%$ [ [4]. This is a similar difference compared with the values we report here of an average $\Delta^{65} \mathrm{Cu}$ between SOD and MT of $0.41 \%$ o (SD 0.3\%o) (Table 1). Albarède et al. [12] found that the copper isotope compositions of erythrocytes were heavier than serum by $0.95 \%$ o for males and $0.60 \%$ o for females. The isotopically-light serum composition was attributed to a signature from liver metallothionein stores, whilst the erythrocyte SOD1 binding was deemed responsible for the heavier composition. The magnitude and direction of the isotopic difference between these two bonding environments in both studies echo the relative fractionation seen here for both males and females (Table 1). However, the isotopic compositions of the SOD and MT fractions were different relative to isotopic reference material NIST $976 \mathrm{Cu}$. This may indicate that the delivery and distribution of $\mathrm{Cu}$ in the brain occurs either (i) independently of the copper source in the erythrocyte and serum pools, which are isotopically heavy and, in the case of serum, predominately bound to ceruloplasmin via N, or (ii) the presence of additional processes that affect the isotopic composition of $\mathrm{Cu}$ available for incorporation to proteins between the blood pool and the brain (e.g., transport effects driven by copper transporter 1). Overall, the relative isotopic composition of metallothionein and SOD1 in these three studies indicates that this fractionation could be used to investigate upstream processes in biological systems and how diseases may disturb these processes.

Buchl et al. [32] found that the copper isotopic composition of whole mice brain samples was influenced by the presence or absence of a metal binding domain in prion protein $(\operatorname{Pr} \mathrm{P})$. The change in isotopic composition was attributed to the triggering of an alternative, but so far unknown copper regulatory pathway. Interrogating the system with isotopic analysis of individual proteins in such brains, in combination with whole brain analysis, could help identify key mechanisms like these. Overexpression of $\mathrm{PrP}$ also had a limited effect on the copper isotopic composition, with some brain samples becoming heavier, isotopically speaking [32]. The overexpression of $\operatorname{PrP}$ is hypothesized to 
upregulate the expression of SOD [33]. The isotopically-heavy SOD value obtained here supports this hypothesis when coupled with the data obtained for whole mouse brains by Buchl et al. [32]. Although a greater number of samples were required, the gender-normalised differences between Alzheimer's disease and healthy controls indicate that this technique can be a useful assay to assess how copper transport processes are disturbed in this disease.

The usefulness of this assay to probe the copper transport mechanisms in diseased states depends on its repeatability. The separation of three aliquots of one specimen into metallothionein and superoxide dismutase fractions and the comparison of these fractions with the original bulk brain homogenate tested the repeatability of the size exclusion fractionation. The copper isotopic composition of metallothionein was lighter and superoxide dismutase (SOD) heavier relative to bulk brain homogenate (Table 2). The mean difference between the two complexes was $\Delta^{65} \mathrm{Cu}=0.59 \%$, which is significantly different from the 2SD across replicates $\left(\delta^{65} \mathrm{Cu}_{\mathrm{MT}} 2 \mathrm{SD}= \pm 0.21 \%\right.$ o, $\delta^{65} \mathrm{Cu}_{\mathrm{SOD}} 2 \mathrm{SD}= \pm 0.33 \%$, $t$-test $\left.p=0.006\right)$. The spread in the data obtained from biological sample sets is normally seen due to natural variation, and whilst this was still the case for high precision isotopic data, the resolution of these data was greater than typically seen for biomedical data. Harrington et al. [34] demonstrated that HPLC-mediated separation of metallo-protein species from bulk homogenate did not result in the exchange of the metal centres, which supports that the data obtained here are a true reflection of the isotopic composition of these proteins in vivo.

Table 2. The copper isotopic composition of metallothionein and superoxide dismutase as isolated from the brain homogenates of a male Alzheimer's disease patient.

\begin{tabular}{cccc}
\hline Sample & Total Cu (ng) & $\boldsymbol{\delta}^{\mathbf{6 5}} \mathbf{C u}(\mathbf{\% o})$ & $\boldsymbol{\Delta}^{\mathbf{6 5}} \mathbf{C u}(\mathbf{\% o})$ \\
\hline Bulk Brain & 635 & -0.09 & \\
Metallothionein & & & \\
Replicate 1 & 43 & -0.17 & \\
Replicate 2 & 37 & -0.21 & \\
Replicate 3 & 45 & -0.37 & \\
Mean (SD) & & $-0.25(0.11)$ & \\
Superoxide dismutase & 168 & & \\
Replicate 1 & 130 & 0.50 & 0.17 \\
Replicate 2 & 166 & 0.34 & 0.38 \\
Replicate 3 & & 0.34 & \\
Mean (SD) & & & 0.73 \\
SOD-MT Pair 1 & & & $0.17)$ \\
SOD-MT Pair 2 & & & \\
SOD-MT Pair 3 & & & \\
Mean (SD) & & &
\end{tabular}

Uncertainty (2 s.d.) for individual multiple-collector inductively-coupled plasma mass spectrometry (MC-ICP-MS) sessions $< \pm 0.15 \%$ o. In-house reference material Romil $\mathrm{Cu}$ [35] used for data collection. All data are expressed relative to NIST $976 \mathrm{Cu}$ utilizing conversion factors presented by Moeller et al. [36]. ** Statistically heavier than the metallothionein fraction, $p=0.006$, two-tailed $t$-test.

To develop a better understanding of the abundance of the available copper proteins present in the sample, we used size exclusion chromatography directly connected to an ICP-MS. Replicate injections of the same brain homogenate that was used for the isotopic ratio determination demonstrated that the SOD and metallothionein peaks together represented $84 \%$ of the total soluble copper (Figure 1). Reproducibility between size exclusion chromatography purification runs of the protein samples was $<2 \%$ with regards to elution volume $[37,38]$ and was typical for human-based populations. This is reflected in the replicates presented in Table 2. The copper in the MT peak is most likely bound to MT3 as MT1 and MT2 are mostly Zn-containing [39]. One caveat regarding the amount of Cu bound to $\mathrm{MT}$ is that $\mathrm{Cu}^{+}$is not air stable in an oxygen-rich environment, and the Cu could have migrated from other $\mathrm{Cu}$ proteins (e.g., ATOX1) after death or during the homogenisation process. The major source of this potentially migrated $\mathrm{Cu}$ is also sulphur binding sites; therefore, the isotopic signature is 
unlikely to be affected by this process; however, future studies under anaerobic conditions or with model cellular systems will be required to determine the extent of $\mathrm{Cu}$ migration to MT3. Isotopic mass balance indicated that there are one or more sources of isotopically-light copper in the remaining $16 \%$ of bulk brain homogenate copper budget to account for the difference between the bulk brain $(-0.09 \%$ o $)$ and the sum of MT and SOD Cu $(+0.21 \%$ o for specimen AD1. The homogeneity of the brain sample, whilst sufficient for typical biological analysis and the associated uncertainty, such as total protein levels or total metal concentrations, may not be homogenous at the isotopic scale, which was detectable at the level of precision employed here. A subtle variation in each replicate injected into the FPLC might be responsible for the small differences observed. Western blot (Figure 2) of the isolated protein showed overlap in Fraction 10. This fraction was discarded due to this overlap; therefore, the protein collection was not quantitative, and uncertainty could have been introduced. In addition, the baseline level of Figure 1 indicates that there may be small contributions from other proteins in the fractions; however, the majority of the $\mathrm{Cu}$-containing proteins in these fractions were $\mathrm{MT}$ and $\mathrm{SOD}$, and therefore, they dominated the isotopic signature. Increased resolution of protein separation could avoid these two potential artefacts and will be the subject of future work.

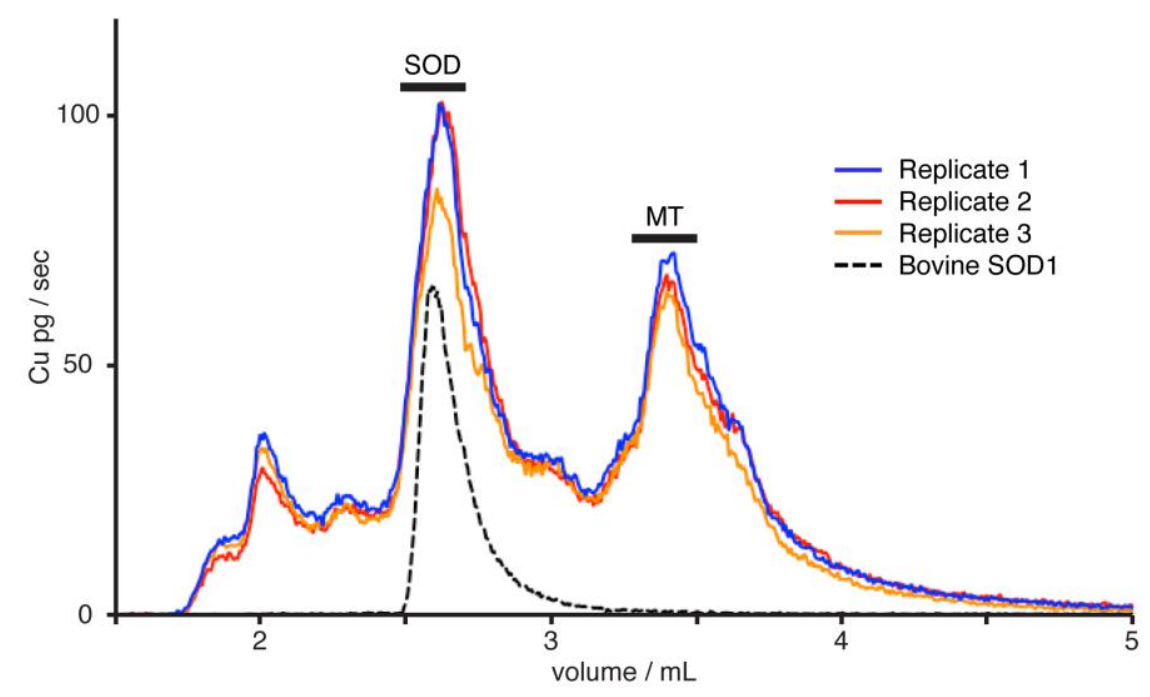

Figure 1. Size exclusion ICP-MS of copper proteins in human brain homogenate. The peak corresponding to the elution of $\mathrm{Cu}$ and $\mathrm{Zn}$ superoxide dismutase (SOD) and metallothionein (MT) are labelled. Bovine SOD was used as a standard (dashed line). The area of the SOD and the MT Cu peak comprise ca. $80 \%$ of the total soluble copper in human frontal cortex. Approximately $15 \%$ of the total $\mathrm{Cu}$ in the soluble fraction eluted between $1.5-2.4 \mathrm{~mL}$.

This study indicates that the isotopic composition of metals bound in proteins could be resolved through purification of such proteins from the sample matrix. Increasing the resolution of HPLC separation to allow quantitative isolation of the proteins from one another coupled with increased sample numbers will provide novel information about the transport of metals in the human body. Comparisons of protein isotopic data between healthy candidates and those with conditions where metal metabolism is indicated, such as Alzheimer's disease, Parkinson's disease and amyotrophic lateral sclerosis, could supplement changes in metal concentrations and provide further insight into the mechanisms of disease. Overall, this workflow can be used as a guide to investigate the role of protein ligands and specific proteins on isotopic fractionation processes for copper and other essential elements such as zinc and iron. 
A

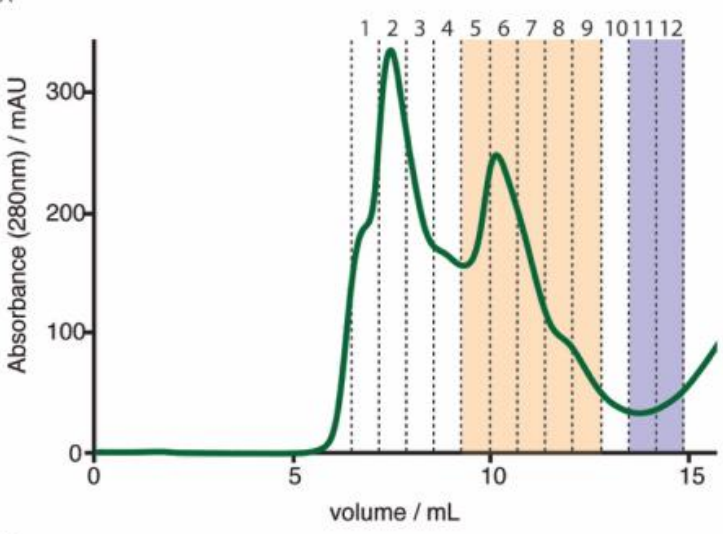

B
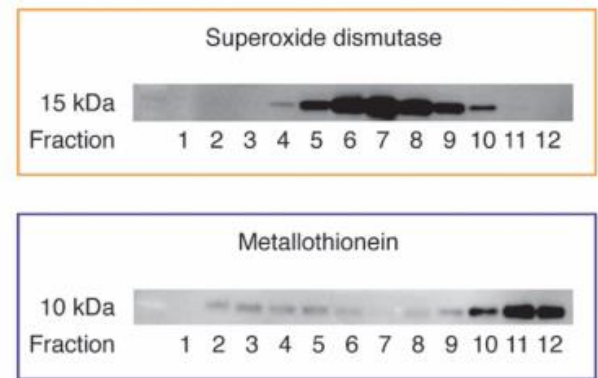

C

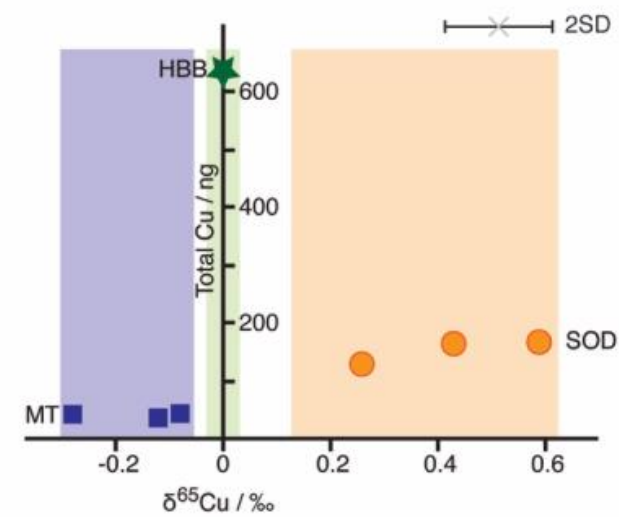

Figure 2. (A) Size exclusion chromatography fractionation of soluble human brain homogenate with the collected fraction indicated by dashed lines; elution of proteins was monitored at 280-nm absorbance; (B) the collected fractions were subjected to Western blot analysis to determine the fractions containing metallothionein (MT; $\mathbf{\square}$ ) and superoxide dismutase (SOD; $\bullet$ ); (C) the replicates of the measured $\mathrm{Cu}$ isotopic ratio and the total amount of $\mathrm{Cu}$ in the MT or SOD fraction are shown relative to bulk brain homogenate $(\mathrm{HBB} ; \star)$. Superoxide dismutase contains copper isotopically heavier than bulk brain and metallothionein.

\section{Materials and Methods}

Fresh frozen frontal cortex was prepared as previously described [40] from male and female patients with Alzheimer's disease (National Institute on Aging (NIA) Reagan criteria) and no brain disease (Table 3). The choice of samples was to gain a small snapshot into the variations that are seen in these conditions to aid the future choice of this precious specimen type for future study. For one specimen (AD1), triplicate samples were taken to test repeatability. Ethical approval for this study was provided by The University of Melbourne Human Research Ethics Committee (I.D. 1136882, 15 February 2017). 
Table 3. Characteristics of donated specimens used in this study.

\begin{tabular}{|c|c|c|c|c|}
\hline Sample Code & Disease State of Brain & Sex & Age & PMI ${ }^{1}$ \\
\hline $\mathrm{AD} 1^{2}$ & Alzheimer's disease & Male & 70 & \\
\hline $\mathrm{AD} 2^{2}$ & Alzheimer's disease & Male & 75.4 & 18.5 \\
\hline $\mathrm{AD}^{2}$ & Alzheimer's disease & Female & 76.8 & 31.0 \\
\hline CON1 & Healthy & Male & 76.9 & 49.0 \\
\hline $\mathrm{CON} 2^{3}$ & Healthy & Female & $76.8^{3}$ & $40.3^{3}$ \\
\hline
\end{tabular}

${ }^{1}$ PMI: post-mortem index; ${ }^{2}$ NIA Reagan criteria; ${ }^{3}$ mean value of two female samples combined prior to isotopic analysis. Individual ages, 78.8 and 74.8; individual PMI, 19 and 61.5.

Briefly, $0.5 \mathrm{~g}$ of grey matter was dissected from fresh frozen tissue and homogenised in Tris-buffered saline (TBS, $50 \mathrm{mM}$ Tris $\mathrm{pH}$ 8.0, $100 \mathrm{mM} \mathrm{NaCl}$ with EDTA-free protease inhibitors (Roche, Castle Hill, Australia)) at a ratio of 1:4 (tissue: buffer, $w / v$ ). Homogenisation was conducted with BioMasher (Omni International, Kennesaw, Australia) following the manufacturer's protocol. After centrifugation at $100,000 \times g$ for $30 \mathrm{~min}$, the TBS supernatant was separated through a Superdex 75 10/300 size exclusion column using an Amersham Biosciences FPLC (injection volume $0.5 \mathrm{~mL}$ ). The column was conditioned with trace metal-free $200 \mathrm{mM}$ ammonium nitrate (Sigma, Castle Hill, Australia) buffer ( $\mathrm{pH}$ 7.7), and calibrated with ribonuclease A (13.7 kDa, GE Healthcare Life Sciences, Silverwater, Australia), bovine serum albumin (67 kDa, Sigma) and bovine superoxide dismutase 1 ( $32 \mathrm{kDa}$, Sigma). A blank separation was performed by injecting the TBS buffer used for homogenisation followed by separations of brain homogenate. Fractions were collected in $0.7-\mathrm{mL}$ aliquots in acid-cleaned centrifuge tubes. Western blot analysis was performed on $100-\mu \mathrm{L}$ aliquots of the collected fractions to determine the elution of SOD1 (Abcam, ab16831, rabbit) and metallothionein (Dako, Clone E9, mouse) (Figure 2). Size exclusion ICP-MS was conducted as previously described [28,41]. For specimen AD1, Western blot analysis was only performed for Replicate 2 .

Samples were freeze-dried prior to shipping to the UK. Samples were analysed for copper isotopic composition at the University of Oxford, Department of Earth Sciences. Quartz sub-boiled distilled $\mathrm{HNO}_{3}$ and $\mathrm{HCl}$ were used throughout and diluted with $18.2 \mathrm{M} \Omega \mathrm{cm} \mathrm{H}_{2} \mathrm{O}$ when required. Romil $30 \%$ $(v / v) \mathrm{H}_{2} \mathrm{O}_{2}$ was used for oxidation when needed. All sample handling was performed in pre-cleaned PFA, PTFE, or HDPE within a laminar flow hood to ensure minimum metal contamination. Fractions incorporating the same protein were combined into one PTFE inset vial and dissolved using microwave digestion [42]. Post-digestion, copper was quantitatively purified from the sample matrix using anion exchange chromatography [8]. The copper isotope composition was determined on a Nu Plasma HR instrument, in medium resolution [8,43]. The total procedural blank was $<1 \mathrm{ng}$, which is $<2 \%$ of the $\mathrm{Cu}$ measured.

\section{Conclusions}

This study indicates that the isotopic composition of metals bound in proteins could be resolved through purification of such proteins from the sample matrix. Increasing the resolution of HPLC separation to allow quantitative isolation of the proteins from one another coupled with increased sample numbers will provide novel information about the transport of metals in the human body. Comparisons of protein isotopic data between healthy candidates and those with conditions where metal metabolism is indicated, such as Alzheimer's disease, Parkinson's disease and amyotrophic lateral sclerosis, could supplement changes in metal concentrations and provide further insight into the mechanisms of disease. Overall this workflow can be used as a guide to investigate the role of protein ligands and specific proteins on isotopic fractionation processes for copper and other essential elements such as zinc and iron.

Author Contributions: Conceptualization, F.L. and B.R.R.; methodology, F.L., C.A.M. and B.R.R.; formal analysis, F.L. and B.R.R.; investigation, F.L. C.A.M., A.N.H. and B.R.R.; resources, C.A.M.; writing, original draft preparation, F.L.; writing, review and editing, F.L., A.N.H. and B.R.R.; funding acquisition, F.L., A.N.H. and B.R.R. 
Funding: This study was funded through Royal Society International Exchanges Grant IE140089 to F.L. and a Science and Technology Facilities Council (STFC) Grant (ST/M001318/1) and European Research Council (ERC) Advanced Fellowship (247422) to A.N.H. We acknowledge funding from the Victorian Government's Operational Infrastructure Support Program and the Australian Research Council Linkage Projects Scheme to B.R.R. LP140100095 (with Agilent Technologies). Partial support is acknowledged from the National Health and Medical Research Council (1061550 and 1138673), the Cooperative Research Centre for Mental Health, the Motor Neuron Disease Research Institute of Australia, and the Neuroproteomics Facility.

Acknowledgments: The authors would like to thank George Ganio for Western blot analysis, Anne Roberts for sample preparation, Paul Adlard for the gift of the metallothionein antibody, Colin Masters for support, and Jim Camakaris and his team for hosting F.L. Tissues were received from the Victorian Brain Bank Network, supported by The University of Melbourne, Alfred Hospital, the Victorian Forensic Institute of Medicine, the National Health and Medical Research Council.

Conflicts of Interest: B.R.R. receives financial support from Agilent Technologies.

\section{References}

1. Roberts, B.R.; Bush, T.M.; Masters, A.I.; Ryan, C.L.; Duce, J.A. The role of metallobiology and amyloid- $\beta$ peptides in Alzheimer's disease. J. Neurochem. 2012, 120, 149-166. [CrossRef] [PubMed]

2. Johnson, C.M.; Beard, B.L. Biogeochemical cycling of iron isotopes. Science 2005, 309, 1025-1027. [CrossRef] [PubMed]

3. Anbar, A. Iron stable isotopes: Beyond biosignatures. Earth Planet. Sci. Lett. 2004, 217, 223-236. [CrossRef]

4. Zhu, X.K.; Guo, Y.; Williams, R.J.P.; O'Nions, R.K.; Matthews, A.; Belshaw, N.S.; Canters, G.W.; de Waal, E.C.; Weser, U.; Burgess, B.K.; et al. Mass fractionation processes of transition metal isotopes. Earth Planet. Sci. Lett. 2002, 200, 47-62. [CrossRef]

5. Cadiou, J.L.; Pichat, S.; Bondanese, V.P.; Soulard, A.; Fujii, T.; Albarède, F.; Oger, P. Copper transporters are responsible for copper isotopic fractionation in eukaryotic cells. Sci. Rep. 2017, 7, 44533. [CrossRef] [PubMed]

6. Aramendia, M.; Rello, L.; Resano, M.; Vanhaecke, F. Isotopic analysis of $\mathrm{Cu}$ in serum samples for diagnosis of Wilson's disease: A pilot study. J. Anal. At. Spectrom. 2013, 28, 675-681. [CrossRef]

7. Balter, V.; Nogueira da Costa, A.; Bondanese, V.P.; Jaouen, K.; Lamboux, A.; Sangrajrang, S.; Vincent, N.; Fourel, F.; Telouk, P.; Gigou, M.; et al. Natural variations of copper and sulfur stable isotopes in blood of hepatocellular carcinoma patients. Proc. Nat. Acad. Sci. USA 2015, 112, 982-985. [CrossRef]

8. Costa-Rodriguez, M.; Anoushkina, Y.; Lauwens, S.; Van Vlierberghe, H.; Delanghe, J.; Vanhaecke, F. Isotopic analysis of $\mathrm{Cu}$ in blood serum by multi-collector ICP-mass spectrometry: A new approach for the diagnosis and prognosis of liver cirrhosis? Metallomics 2015, 7, 491-498. [CrossRef]

9. Larner, F.; Woodley, L.N.; Shousha, S.; Moyes, A.; Humphreys-Williams, E.; Strekopytov, S.; Halliday, A.N.; Rehkämper, M.; Coombes, R.C. Zinc isotopic compositions of breast cancer tissue. Metallomics 2015, 7, 112-117. [CrossRef]

10. Telouk, P.; Puisieux, A.; Fujii, T.; Balter, V.; Bondanese, V.P.; Morel, A.-P.; Clapisson, G.; Lamboux, A.; Albarède, F. Copper isotope effect in serum of cancer patients. A pilot study. Metallomics 2015, 7, $299-308$. [CrossRef]

11. Lauwens, S.; Costas-Rodrigues, M.; Van Vlierberghe, H.; Vanhaecke, F. Cu isotopic signature in blood serum of liver transplant patients: A follow up study. Sci. Rep. 2016, 6, 30683. [CrossRef] [PubMed]

12. Albarède, F.; Telouk, P.; Lamboux, A.; Jaouen, K.; Balter, V. Isotopic evidence of unaccounted for Fe and Cu erythropoietic pathways. Metallomics 2011, 3, 926-933. [CrossRef] [PubMed]

13. Jaouen, K.; Gibert, M.; Lamboux, A.; Telouk, P.; Fourel, F.; Albarède, F.; Alekseev, A.N.; Crubezy, E.; Balter, V. Is aging recorded in blood $\mathrm{Cu}$ and $\mathrm{Zn}$ isotope compositions? Metallomics 2013, 5, 1016-1024. [CrossRef] [PubMed]

14. Van Heghe, L.; Engstrom, E.; Rodushkin, I.; Cloquet, C.; Vanhaecke, F. Isotopic analysis of the metabolically relevant transition metals $\mathrm{Cu}, \mathrm{Fe}$ and $\mathrm{Zn}$ in human blood from vegetarians and omnivores using multi-collector ICP-mass spectrometry. J. Anal. At. Spectrom. 2012, 27, 1327-1334. [CrossRef]

15. Van Heghe, L.; Deltombe, O.; Delanghe, J.; Depypere, H.; Vanhaecke, F. The influence of menstrual blood loss and age on the isotopic composition of $\mathrm{Cu}, \mathrm{Fe}$ and $\mathrm{Zn}$ in human whole blood. J. Anal. At. Spectrom. 2014, 29, 478-482. [CrossRef] 
16. Fujii, T.; Moynier, F.; Telouk, P.; Fourel, F.; Abe, M. Experimental and theoretical investigation of isotope fractionation of zinc between aqua, chloro and macrocyclic complexes. J. Phys. Chem. A 2010, 114, $2543-2552$. [CrossRef] [PubMed]

17. Fujii, T.; Moynier, F.; Abe, M.; Nemoto, K.; Albarède, F. Copper isotope fractionation between aqueous compounds relevant to low temperature geochemistry and biology. Geochim. Cosmochim. Acta 2013, 110, 29-44. [CrossRef]

18. Moynier, F.; Fujii, T.; Shaw, A.S.; Le Borgne, M. Heterogeneous distribution of natural zinc isotopes in mice. Metallomics 2013, 5, 693-699. [CrossRef]

19. Navarette, J.U.; Borrock, D.M.; Viverous, M.; Ellzey, J.T. Copper isotope fractionation during surface adsorption and intracellular incorporation by bacteria. Geochim. Cosmochim. Acta 2011, 75, 784-799. [CrossRef]

20. Pokrovsky, O.S.; Viers, J.; Emnova, E.; Kompantseva, E.I.; Freydier, R. Copper isotope fractionation during during its interaction with soil and aquatic microorganisms and metal oxy(hydr)oxides: Possible structural control. Geochim. Cosmochim. Acta 2008, 72, 1742-1757. [CrossRef]

21. Weiss, D.J.; Mason, T.F.D.; Zhao, F.J.; Kirk, G.J.D.; Coles, B.J.; Horstwood, M.S.A. Isotopic discrimination of zinc in higher plants. New Phytol. 2004, 165, 703-710. [CrossRef] [PubMed]

22. Tennant, A.; Rauk, A.; Wieser, M.E. Computational modelling of the redistribution of copper isotopes by proteins in the liver. Metallomics 2017, 9, 1809-1819. [CrossRef] [PubMed]

23. Krizkova, S.; Kepinska, M.; Emri, G.; Rodrigo, M.A.M.; Tmejova, K.; Nerudova, D.; Kizek, R.; Adam, V. Microarray analysis of metallothioneins in human diseases-A review. J. Pharm. Biomed. Anal. 2016, 117, 464-473. [CrossRef] [PubMed]

24. Fukai, T.; Ushio-Fukai, M. Superoxide dismutases: Role in redox signalling, vascular function and diseases. Antioxid. Redox Signal. 2001, 15, 1583-1606. [CrossRef] [PubMed]

25. Rakhit, R.; Chakrabartty, R.A. Structure, folding, and misfolding of $\mathrm{Cu}, \mathrm{Zn}$ superoxide dismutase in amyotrophic lateral sclerosis. Biochim. Biophys. Acta 2006, 1762, 1025-1037. [CrossRef]

26. Ebadi, M.; Brown-Borg, H.; El Refaey, H.; Singh, B.B.; Garrett, S.; Shavali, S.; Sharma, S.K. Metallothionein-mediated neuroprotection in genetically engineered mouse models of Parkinson's disease. Mol. Brain Res. 2005, 134, 67-75. [CrossRef] [PubMed]

27. Uchida, Y.; Takio, K.; Titani, K.; Ihara, Y.; Tomonaga, M. The growth inhibitory factor that is deficient in the Alzheimer's disease brain is a 68 amino acid metallothionein-like protein. Neuron 1991, 7, 337-347. [CrossRef]

28. Roberts, B.R.; Lim, N.K.H.; McAllum, E.J.; Donnelly, P.S.; Hare, D.J.; Doble, P.A.; Turner, B.J.; Price, K.A.; Lim, S.C.; Paterson, B.M.; et al. Oral treatment with $\mathrm{Cu}(\mathrm{II})(\mathrm{atsm})$ increases mutant SOD1 in vivo but protects motor neurons and improves the phenotype of a transgenic mouse model of amyotrophic lateral sclerosis. J. Neurosci. 2014, 34, 8021-8031. [CrossRef]

29. Williams, J.R.; Trias, E.; Beilby, P.R.; Lopez, N.I.; Labut, E.M.; Bradford, C.S.; Roberts, B.R.; McAllum, E.J.; Crouch, P.J.; Rhoads, T.W.; et al. Copper delivery to the CNS by CuATSM effectively treats motor neuron disease in SOD(G39A) mice co-expressing the Copper-Chaperone-for-SOD. Neurobiol. Dis. 2016, 89, 1-9. [CrossRef]

30. Chasapis, C.T.; Luotsidou, A.C.; Spiliopoulou, C.A.; Stefanidou, M.E. Zinc and human health: An update. Arch. Toxicol. 2012, 86, 521-534. [CrossRef]

31. Tainer, J.A.; Getzoff, E.D.; Richardson, J.S.; Richardson, D.C. Structure and mechanism of copper, zinc superoxide dismutase. Nature 1983, 306, 284-287. [CrossRef] [PubMed]

32. Buchl, A.; Hawkesworth, C.J.; Vala Ragnarsdottir, K.; Brown, D.R. Repartitioning of Cu and Zn isotopes by modified protein expression. Geochem. Trans. 2008, 9, 11-17. [CrossRef] [PubMed]

33. Harrington, C.F.; Vidler, D.S.; Watts, M.J.; Hall, J.F. Potential for using isotopically altered metalloproteins in species-specific isotope dilution analysis of proteins by HPLC coupled to inductively coupled plasma mass spectrometry. Anal. Chem. 2005, 77, 4034-4041. [CrossRef] [PubMed]

34. Westergard, L.; Christensen, H.M.; Harris, D.A. The cellular prion protein (PrPc): Its physiological function and role in disease. Biochim. Biophys. Acta 2007, 1772, 629-644. [CrossRef] [PubMed]

35. Larner, F.; Rehkämper, M.; Coles, B.J.; Kreissig, K.; Weiss, D.J.; Sampson, B.; Unsworth, C.; Strekpytov, S. A new separation procedure for $\mathrm{Cu}$ prior to stable isotope analysis by MC-ICP-MS. J. Anal. At. Spectrom. 2011, 26, 1627-1632. [CrossRef] 
36. Moeller, K.; Schoenberg, R.; Pedersen, R.-B.; Weiss, D.; Dong, S. Calibration of the new certified reference materials ERM-AE633 and ERM-AE647 for copper and IRMM-3702 for zinc isotope amount ratio determinations. Geostand. Geoanal. Res. 2012, 36, 177-199. [CrossRef]

37. Hare, D.J.; Doecke, J.D.; Faux, N.G.; Rembach, A.; Volitakis, I.; Fowler, C.J.; Grimm, R.; Doble, P.A.; Cherny, R.A.; Masters, C.L.; et al. Decreased plasma iron in Alzheimer's disease is due to transferrin desaturation. ACS Chem. Neurosci. 2015, 6, 398-402. [CrossRef]

38. Rembach, A.; Hare, D.J.; Doecke, J.D.; Burnham, S.C.; Volitakis, I.; Fowler, C.J.; Cherny, R.A.; McLean, C.; Grimm, R.; Martins, R.; et al. Decreased serum zinc is an effect of ageing and not Alzheimer's disease. Metallomics 2014, 6, 1216-1219. [CrossRef]

39. Krężel, A.; Maret, W. The functions of metamorphic metallothioneins in zinc and copper metabolism. Int. J. Mol. Sci. 2017, 18, 1237. [CrossRef]

40. Roberts, B.R.; Hare, D.J.; McLean, C.A.; Conquest, A.; Lind, M.; Li, Q.X.; Bush, A.I.; Masters, C.L.; Morganti-Kossmann, M.C.; Frugier, T. Traumatic brain injury induces elevation of Co in the human brain. Metallomics 2015, 7, 66-70. [CrossRef]

41. Lothian, A.; Roberts, B.R. Standards for quantitative metalloproteomic analysis using size exclusion ICP-MS. J. Vis. Exp. 2016, 110, 53737. [CrossRef] [PubMed]

42. Larner, F.; Dogra, Y.; Dybowska, A.; Fabrega, J.; Stolpe, B.; Bridgestock, L.J.; Goodhead, R.; Weiss, D.J.; Moger, J.; Lead, J.R.; et al. Tracing bioavailability of $\mathrm{ZnO}$ nanoparticles using stable isotope labeling. Environ. Sci. Technol. 2012, 46, 12137-12145. [CrossRef] [PubMed]

43. Larner, F.; Sampson, B.; Rehkämper, M.; Weiss, D.J.; Dainty, J.R.; O’Riordan, S.; Panetta, T.; Bain, P.G. High precision isotope measurements reveal poor control of copper metabolism in Parkinsonism. Metallomics 2013, 5, 125-132. [CrossRef] [PubMed]

(C) 2019 by the authors. Licensee MDPI, Basel, Switzerland. This article is an open access article distributed under the terms and conditions of the Creative Commons Attribution (CC BY) license (http://creativecommons.org/licenses/by/4.0/). 